\title{
Studying student teachers' concerns, combining image-based and more traditional research techniques
}

\author{
Anja Swennen ${ }^{\mathrm{a}^{\star}}$, Ton Jörg ${ }^{\mathrm{a}}$ and Fred Korthagen ${ }^{\mathrm{b}}$ \\ ${ }^{a}$ Vrije Universiteti Amsterdam, The Netherlands; ${ }^{b}$ University of Utrecht, The \\ Netherlands
}

In a study of student teachers' concerns, a combination of image-based and more traditional research techniques was used. The first year student teachers appeared to be most concerned about matters that, in their view, form the core task of teaching, such as 'selecting and teaching content well', 'motivating pupils to learn' and 'adapting myself to the needs of different pupils'. They are less concerned about matters that are not central to the immediate task of teaching or that they, as student teachers, cannot influence. In line with other research, their concerns remained reasonably stable during their first year of teaching. Drawings appeared to be a reasonably reliable and valid means of assessing concerns and seemed to elicit a specific type of information when compared with more widely used research techniques such as the card sorting technique and interviews used in this research.

Dans une étude concernant les préoccupations d'étudiants futurs enseignants, plusieurs techniques de recherche diverses ont été utilisées: des techniques basées sur l'image et d'autres plus traditionnelles. Les étudiants de première année se révèlent plus sensibles à des choses qui, à leur sens, constituent l'essence même du travail de l'enseignant comme 'bien choisir et enseigner un contenu', 'motiver les élèves à apprendre' et 's'adapter aux divers besoins des élèves'. Ils s'avèrent en revanche moins concernés par des sujets ne jouant pas immédiatement un rôle central ou direct dans la mission d'enseigner ou sur lesquels, en tant que futur enseignant encore en cours de formation, ils n'ont pas d'influence. Comme l'étayent d'autres recherches, ces préoccupations restent plutôt stables au cours de leur première année d'expérience pratique dans l'enseignement. Les dessins se sont avérés être des moyens assez fiables et valables pour l'évaluation des préoccupations et permettant d'extraire un type d'information spécifique par rapport à d'autres techniques de recherche auxquelles il est plus fréquemment fait appel comme le tri de cartes ou l'interview, également utilisées lors de cette étude.

En un estudio sobre las preocupaciones de los estudiantes de profesorado, se usó una combinación de técnicas de investigación basadas en imágenes y otras técnicas más tradicionales. Parece ser que durante el primer año, a los estudiantes de profesorado les preocupan sobre todo los temas que en su visión constituye la tarea central de la enseñanza, como por ejemplo 'seleccionar y enseñar bien el contenido', 'motivar a los alumnos a aprender' y 'adaptarme a las necesidades de diferentes alumnos'. Les preocupan menos los asuntos no tan directamente relacionados con la

${ }^{\star}$ Corresponding author. Vrije Universiteit, Onderwijscentrum VU, De Boelelaan 1105, $1081 \mathrm{HV}$ Amsterdam, The Netherlands. Email: a.swennen@ond.vu.nl 
enseñanza, o en los que ellos, como estudiantes de profesorado, no pueden influir. En línea con los resultados de otros estudios, sus preocupaciones permanecieron estables durante el primer año de enseñanza. El método de los dibujos demostró ser fiable y válido para evaluar las preocupaciones, y parecía generar un determinado tipo de información en comparación con técnicas más ampliamente usadas, como la técnica de clasificación de cartas y las entrevistas, que también se aplicaron en este estudio.

In einer Studie über die Interessen von Lehrern im ersten Studienjahr wurde eine Kombination aus visuellen und traditionelleren Forschungstechniken gewählt. Die Studenten des ersten Jahres scheinen am meisten an Dingen interessiert zu sein, die ihrer Ansicht nach zu den Kernaufgaben des Lernens gehören, wie zum Beispiel 'richtige Auswahl und Vermittlung des Wissens, 'motivierung von Schülern zu lernen' und 'meine Anpassung an die Bedürfnisse der jeweiligen Schüler'. Sie sind weniger interessiert an Dingen, die nicht zu der unmittelbaren Lehrtätigkeit gehören oder die sie als Student nicht beeinflussen können. Im Rahmen anderer Forschungstechniken waren ihre Interessen im ersten Studienjahr ziemlich konstant. Zeichnungen erwiesen sich als angemessenes und gültiges Mittel zur Bewertung der Interessen und führten zu einer bestimmten Art von Informationen, wenn man Vergleiche mit den weiterverbreiteten Forschungstechniken wie Card-Sorting-Technik und Interviews anstellt, die in dieser Forschung angewandt werden.

\section{Introduction}

Students entering pre-service teacher education are not empty vessels to be filled with ideas about 'good education' (Cole \& Knowles, 1993; Kelchtermans, 1993). As learners, they have experienced many years of education. They have heard stories from and about teachers. They have seen films and television programmes showing stereotyped examples of teaching (Weber \& Mitchell, 1995). They may have had relevant experience in working with children, for instance in sports training or children's holiday camps. Wubbels (1992) argues that the preconceptions about teaching that student teachers bring into teacher education include metaphorical 'world images'. Other researchers also use the term 'images' and claim that images play an important part in shaping behaviour (see, for example, Connelly \& Clandinin, 1984; Denis, 1991). Korthagen (1993) extended this analysis of the nature of the less cognitive aspects of student teachers' mental representations of educational practice. He argues that students' perceptions not only include cognitive elements and imaginative structures, but also feelings, needs, concerns, values and behavioural tendencies.

The research reported here is a collaborative effort of a teacher educator in a teacher education institute for primary school teachers and two researchers in a university institute for the education of prospective secondary teachers. It was decided to study student teachers' concerns about teaching on the basis of their mental images of teaching practice. This choice was further influenced by arguments found in the literature suggesting that both concerns and images are important factors in informing researchers and teacher educators about teachers' professional development. Guillaume and Rudney (1993, p. 65), for example, wrote:

Through examination of student teachers' perceptions and concerns, an insight can be gained about the problems teachers face and the knowledge they find of most worth. By attending to student teachers' concerns we can further understand the processes students undergo to become teachers. 


\section{Theoretical background}

Research on teachers' concerns draws heavily on the work of Fuller (1969). Fuller and Bown (1975) drew a distinction between the development of concerns of teachers and those of student teachers. In the case of student teachers, they distinguished four main stages of concerns. During the first stage pre-teaching concerns are dominant. Student teachers identify with pupils, but with their teachers they do so only in their fantasies. After their first teaching experience, a radical change takes place. Idealized ideas about pupils are replaced by concerns about their own survival. Now the central question is, will I be able to manage the class? Next, student teachers develop concerns about the teaching situation: they become concerned about methods and materials and start looking for new ideas for their lessons. Still, these are concerns about their own performance as a teacher and not concerns about pupils and their learning, which is the fourth category of concerns. At this fourth stage, student teachers have an eye for pupils' social and emotional needs and they become more focused on their relationships with individual children.

There is general agreement about three main categories of concerns: (1) survival concerns, (2) concerns about the task and (3) concerns about the pupils. However, the research in this field provides little evidence of the existence of general stages in the development of concerns: there may be sudden peaks or drops (Janssens, 1989), concerns can show an overlap (Pigge \& Marso, 1987) or concerns about the pupils can play a central role from the very beginning of the professional development of the student teachers (Smith \& Sanche, 1992, 1993). Guillaume and Rudney (1993) give two possible explanations for these different research results. First, student teachers' concerns are influenced by a variety of factors shaping their classroom experiences. A second explanation is that personal characteristics, such as gender and cognitive structure, strongly interact with the development of concerns.

For a long time, studies on concerns were embedded in a more general research strand focusing on teacher development (Pigge \& Marso, 1987; Burden, 1990). In the 1990s research into student teacher concerns became part of the research on teacher cognition (see, for example, Guillaume \& Rudney, 1993). In particular, concerns were more and more studied in relation to teachers' implicit or tacit knowledge. Especially interesting is the link between concerns and emotions. Authors such as Packer and Scott (1992) think about concerns as a motivating factor in the organization of (patterns of) behaviour.

Calderhead (1989), among others, considers images to be a key factor in explaining the professional development of teachers. Students enter pre-service teacher education with images about their future profession and their own role as a teacher. Calderhead (1989, p. 47) says

The term image has been variously used to describe teachers' practical knowledge, though each usage emphasises the experiential basis of teachers' working knowledge, and the importance of large, episodic, particularly visual, memory.

He presents an overview of different types of images, from rather concrete to more abstract. On the highest level of abstraction, an image is a powerful metaphor with 
affective and moral connotations. On a lower level, we find the images of an 'ideal teacher' that students sometimes carry with them as the result of experiences with positive role models. On a still lower level are the images that student teachers have of the contents of particular lessons, for example a mathematics lesson or a physics practical.

In our study we operationalized the concept of image by using student teachers' drawings. We focused on drawings that student teachers made about themselves in relation to their teaching practice situation. In doing so, we are building on earlier studies in which drawings were used to inform researchers (Huibregtse et al., 1994; Weber \& Mitchell, 1995, 1996).

\section{Research design}

The study was carried out in a Dutch teacher education institute for primary teaching. As previously mentioned, this study focused on the student teachers' development during their first year. During this year students become acquainted with school practice, but they do little teaching. The group we studied consisted of 37 students ( 33 women and 4 men) aged between 17 and 20, divided into two first year groups. These were all the full-time first year students in that particular year.

An important argument for studying the development of first year students is that in the Dutch system of higher education the first year is meant for appraisal and selection of students. At the end of the first year teachers in the teacher education institute as well as the student herself/himself must decide whether the student teacher is potentially suited to become a teacher. A second argument is that in some Dutch literature (for example about the National Curriculum for teacher education) it is stated that the student should make a transition from concerns about themselves to concerns about the task of teaching during their first year (see, for example, Proces Management Lerarenopleidingen, 1998). Our last argument is that, as far as we know, there is no research about the concerns of first year student teachers and the development of their concerns.

Based on the general question about the concerns and images of student teachers and their development, the following more specific questions have guided our study.

1. What are the concerns of first year students at the beginning of their preparation programme?

2. What are their concerns after their first teaching practice period (in the first year)?

3. What are their concerns at the end of the first year?

4. What development in concerns, if any, occurs during the first year?

5. Can concerns be assessed in a valid and reliable way using drawings?

To measure the concerns, we used three instruments: a card sorting instrument, drawings made by the student teachers and interviews. In Table 1 we show an overview of the measurements during the first year, which consisted of six institutebased periods of 4-7 weeks and two practice periods of 1 week, after the third and fourth periods. The number of students changed from measurement to measure- 


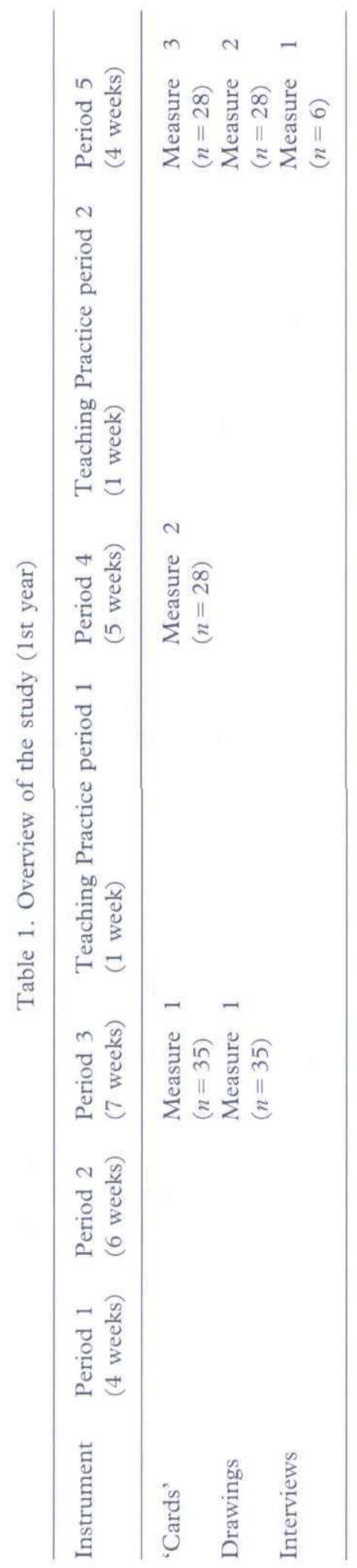




\section{Self concerns}

Figure 1. Items on the cards

Whether the pupils like me or not

Getting a favourable evaluation from my mentor

Pupils who disrupt class

Becoming a good teacher

\section{Instructional concerns}

Selecting and teaching content well

The socio-pedagogical climate

Too many pupils in one class

Adequately presenting all of the required material

Pupils' needs concerns

Diagnosing pupils with learning problems

Being fair and impartial

Adapting myself to the needs of different pupils

Motivating pupils to learn

Overall educational concerns

Lack of freedom to initiate innovative instruction

Staff collaboration

Too many non-instructional duties

Inadequate teaching salaries

ment because of illness or extra time spent at their practice school. Two students left the programme before the second and third measurements.

\section{The card sorting instrument}

We developed the card sorting instrument not only as a research instrument, but also as an instrument that can be used to promote reflection by student teachers about their own concerns. The instrument is based on the Teacher Concern Checklist developed by Fuller and Borich (Fuller \& Borich, 1988; see also Borich, 1996). The original checklist consisted of 50 items and was adapted until 16 items remained (see Figure 1). These 16 items were transferred to cards and a set of cards was made for each student. Students were asked to rank the cards from the item concerning them most to the item concerning them least or not at all.

For each of the three measurements (see Table 1) the mean rank number was calculated, as well as the standard deviation. The ranking scores could be compared to assess an overall change in the development of concerns (using Friedman's test). The remarks of all the students were analysed in order to gain an insight into the students' interpretations of the items.

\section{The drawings}

We asked the students to make a drawing of themselves in relation to the school they had been working in during their teaching practice period. A total of 64 drawings were made: 34 at the beginning of the year, a week before the teaching practice period, and 30 at the end of the year, a week after the last week of the teaching 
practice period. Each student received paper, (coloured) pencils and crayons. The students were free in their choice of drawing materials.

Analysis of the drawings proceeded in two stages. The purpose of the first stage was to develop categories of concerns based on the drawings. The first author made a description of the main visual aspects (insofar as they are visible in the picture), such as the student herself/himself (role, place in the classroom or playground, clothes, hairstyle, facial expression and so forth), pupils (number, gender, ages, clothes, hairstyles, facial expressions and so forth), mentor, other persons and events (such as teaching, playing with children) and additional text in the pictures written by the student to clarify the drawing. On the basis of this description the similarities and differences between the drawings were determined. The result was a division of the drawings into eight concern categories. The intention was to develop concern categories that emerged from the drawings, not to look for concerns that fitted the previously mentioned concerns of Fuller and Bown (1975), which were the basis of the card sorting instrument.

The reliability of the concern categories was assessed during the second stage. The procedure was as follows. During a pilot, all three authors scored the concerns in the drawings of a group of students, different from the one being studied. Before any scoring took place, a description of the concerns was made and further refined during the pilot. Finally, 28 drawings of the students involved in this study were chosen at random and scored independently by three raters with two questions to be answered: (1) is the category of concern present in this drawing; (2) if it is, to what degree (intensity) is it present, on a scale from 1 (minimum) to 4 (maximum)?

\section{The interviews}

From the group of 37 students we selected six for semi-structured interviews. Because we wanted to interview students who had ranked the cards in accordance with the general results and students who had ranked the cards differently, we wanted to interview a minimum of three students from each group. The interviews were used to enable us to comprehend the meaning students had given to the items on the cards and the drawings. This helped us evaluate the connection between the images embedded in the drawings and the concerns of the student teachers. The interviews were meant to illustrate the outcomes of the analyses of the card sorting instrument and the drawings.

To compare the results of the analyses of the card sorting instrument and the drawings, we only used the first and third rankings. Students were individually asked the following questions:

On the ranking of the cards: (1) what strikes you about how you ranked the cards the first time; (2) what strikes you about how you ranked the cards the last time; (3) how do you explain the similarities and differences between the first and last ranking?

On the drawings of the students: (1) what strikes you about your first drawing; (2) 
what strikes you about your last drawing; (3) How do you explain the similarities and differences between the first and the last drawing?

\section{Findings}

\section{The card sorting instrument}

The scores for all three measurements are shown in Table 2. The items are ranked from the highest to the lowest score for the first measurement, with the mean score being given with the standard deviation. The ranking is based on a score of 1 for the card that a student considered most important and a score of 16 for the least important card.

Of the four concern categories (see Figure 1), the concern category 'pupils' needs concerns' scores the highest. There is a reasonable distance to the score for the second highest category, 'instructional concerns'. The category 'self concerns' appears not to score highly. The fourth category, 'overall educational concerns', scores lowest.

The items that show a high score for all three measurements are: 'selecting and teaching content well', 'motivating pupils to learn' and 'adapting myself to the needs of different pupils'. The comments on the forms and those made in the interviews show that the student teachers regard the importance of these items as self-evident. For example, Loredana said in the interview:

I do find it important to select and teach content well when becoming a teacher. I mean, you have to give the children a good future and that starts with primary education. If you cannot even teach well.

According to the students, motivation is a precondition for children to learn and a precondition for teaching well. For two of the items ranked in the middle, the scores are remarkable: 'becoming a good teacher' and 'pupils who disrupt class'. The first of these items is the only one belonging to the category 'self concerns' that received a relatively high score. There is no other item that so often ended in first place (11 times), but this item has a high standard deviation. The students say that for them 'becoming a good teacher' is important beyond dispute:

It strikes me that I put 'whether I will become a good teacher' top of the list every time. It is not that I have doubts about my abilities, but I simply find it the most important item.

There are also student teachers that give a low score to this item.

It is remarkable that an item such as 'pupils who disrupt class' ends up with a low score. The students we studied seemed to differ from beginning teachers who, according to other research, have deep concerns about 'maintaining discipline' (Veenman, 1984). In the interviews Eileen and Leonie said that they had ranked the item about students disrupting class quite low because they did not have any experience. Leonie said in her interview about the first time that she ranked the cards:

I did not know what to expect exactly. I know what discipline means, but not how to maintain it myself. 


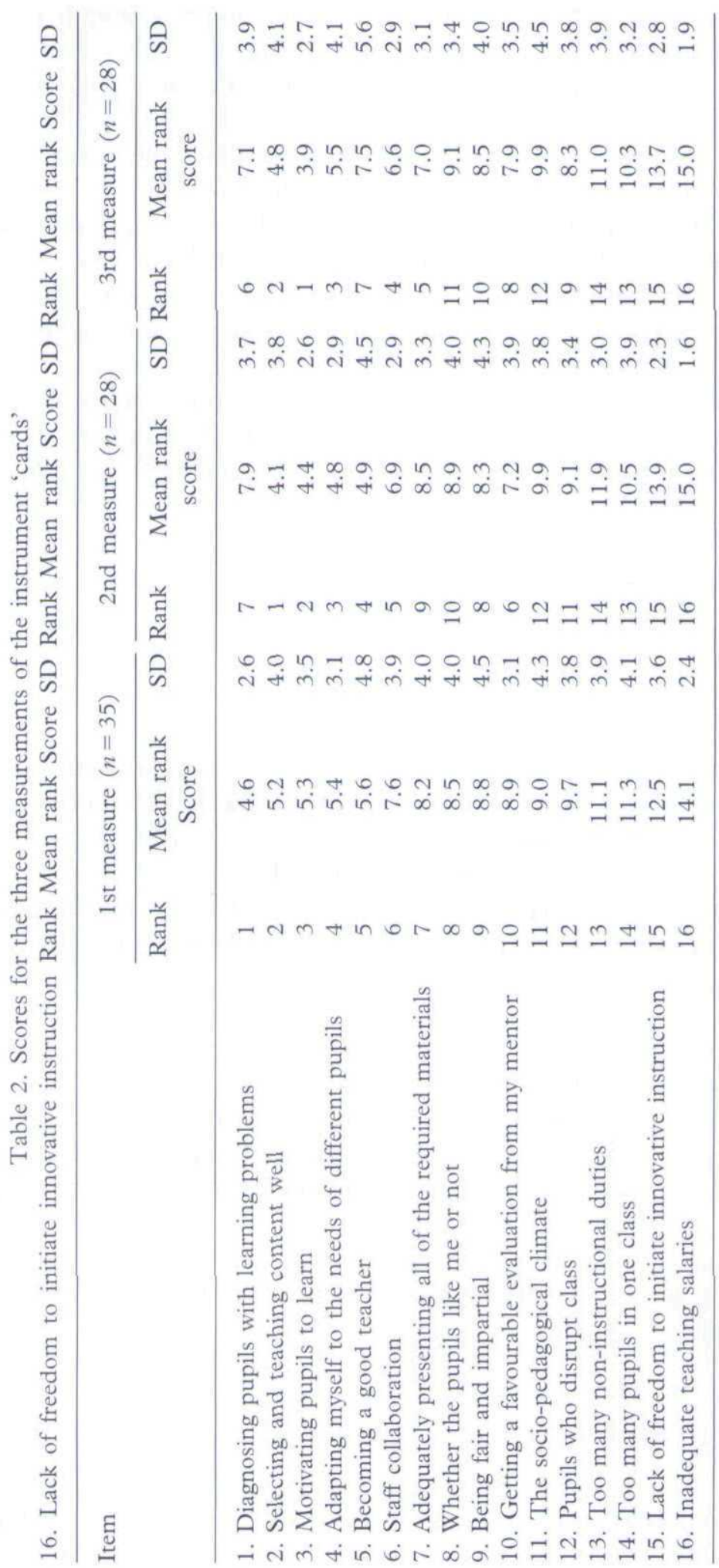


Most items that were ranked low belong to the category 'overall educational concerns'. The comments made by the students show that they think that these aspects may play a more important role in the future, but not at this stage of their development.

Using the Friedman test, we determined whether or not there were significant differences between the three measurements (the fourth research question). The $\chi^{2}$ test gave a value of 0.66 , with a corresponding $P$ value of 0.72 . This means that there are no significant differences between the results of the three measurements. The students' remarks also did not show a change over the year. However, the students made considerably fewer remarks on the forms for the second and third measurement.

On the level of individual items only one item, 'diagnosing pupils with learning needs', showed a significant drop from first place in the first measurement (mean score 4.6), to seventh place (mean 7.9) in the second measurement. Eileen said in her interview:

It is still very important, but at a certain moment I knew the problems, I knew the problems of certain pupils. Just the learning problems, not the rest. And once you know the problems, you pay attention to them, you just do it.

Leonie said about the shift in 'diagnosing pupils with problems':

It doesn't belong to the essence of teaching.

The main conclusion based on analysis of the data gathered with the card sorting instrument is that there is in general no overall change in the concerns of these student teachers during their first year. Although on the whole we can say that students have concerns about what they consider the core of teaching, they also have, not surprisingly, especially before their teaching practice period, pre-teaching concerns. These pre-teaching concerns manifest themselves in an idealized view of teaching and less interest in 'survival concerns'.

There are, however, indications that the students are becoming less idealistic and more realistic about teaching. The drop of the item 'diagnosing pupils with learning needs' and the relatively low rating of the item 'pupils who disrupt class' support this. This conclusion is further supported by the comments about the last item and by the comments about the item about a large number of pupils in class that were made on the card sorting form, as well as the comments made on these items in the interviews.

This shift is in line with the theory of Fuller and Bown (1975), who say that students, once they gain practical experience, become less romantic about teaching.

\section{The drawings}

The first stage analysis of all 64 drawings provided evidence of eight categories of concerns.

1. Concerns about a cosy atmosphere in the classroom. In this category of drawings we see students in front of the class or among the pupils. They sing, read stories 


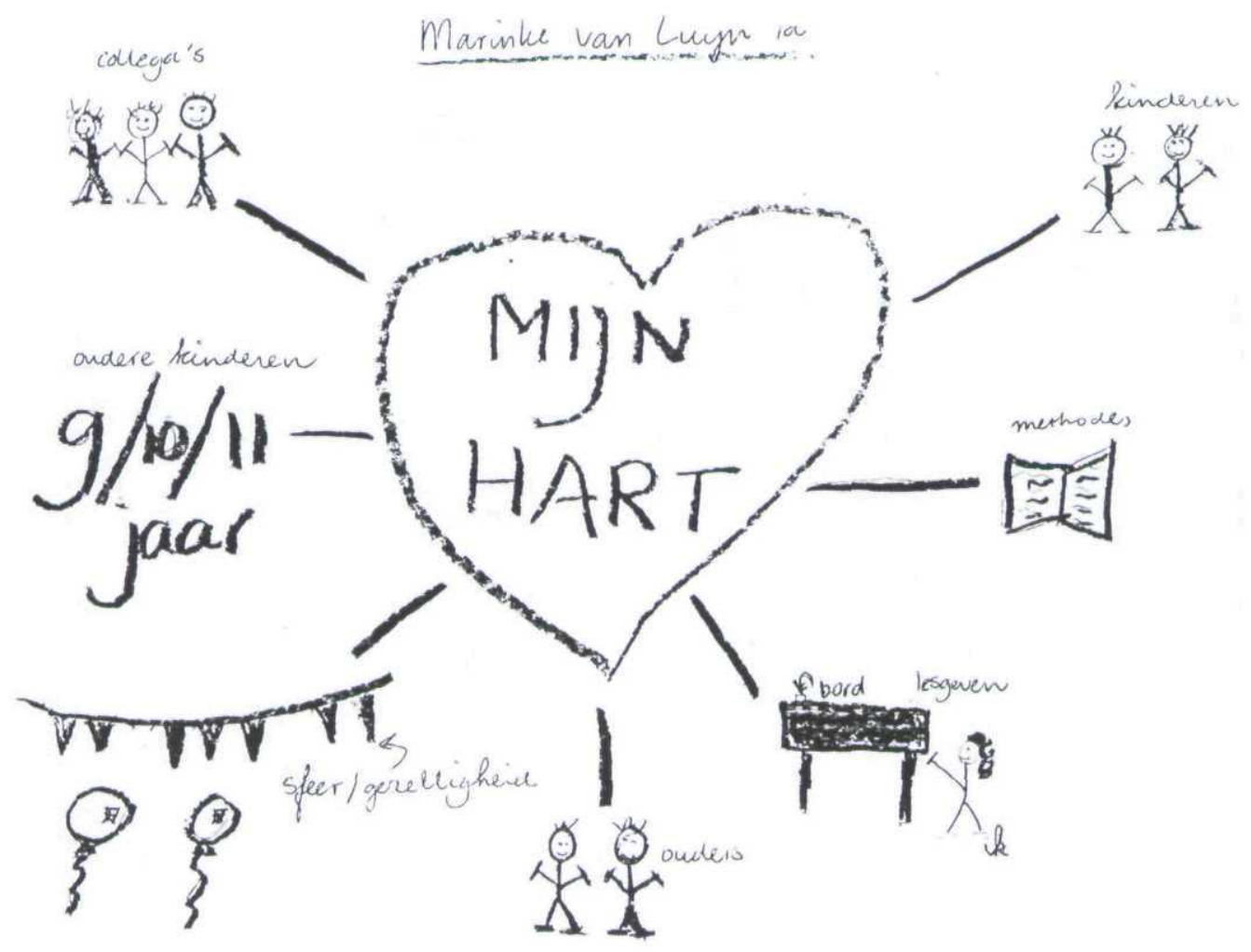

Figure 2. Drawing by Marinke

or celebrate something. Characteristic of these drawings are plants, pictures of pupils, paper chains, drawings on the blackboard and the windows.

2. Concerns about pupils. Pupils are pictured as individuals. The student draws herself/himself as a person paying attention to pupils. Pupils are pictured near the student teachers; sometimes lines indicate a connection between student teachers and pupils. Students sometimes draw a red heart to indicate the (mutual) feelings between themselves and the pupils.

3. Concerns about maintaining discipline. In the drawings pupils are talking or playing with each other in a disruptive way, indicated, for example, by text coming from pupils. Pupils are pictured far from the student.

4. Concerns about the opinion of the mentor. The mentor is visible in the classroom, looking at and listening to the student or the mentor is seen taking notes. The mentor is sometimes pictured with large eyes and ears.

5. Concerns about pupils' learning. In a symbolic way, for instance by drawing lines between the student and the pupil(s), the transmission of knowledge is expressed. In other cases the contents of a subject are visualized on the blackboard (first words to read, sums). Sometimes teaching objects can be seen in the drawings, such as a globe.

6. Concerns about matters outside the classroom. In these drawings students indicate the presence of colleagues, parents, the neighbourhood (see Figure 2). 


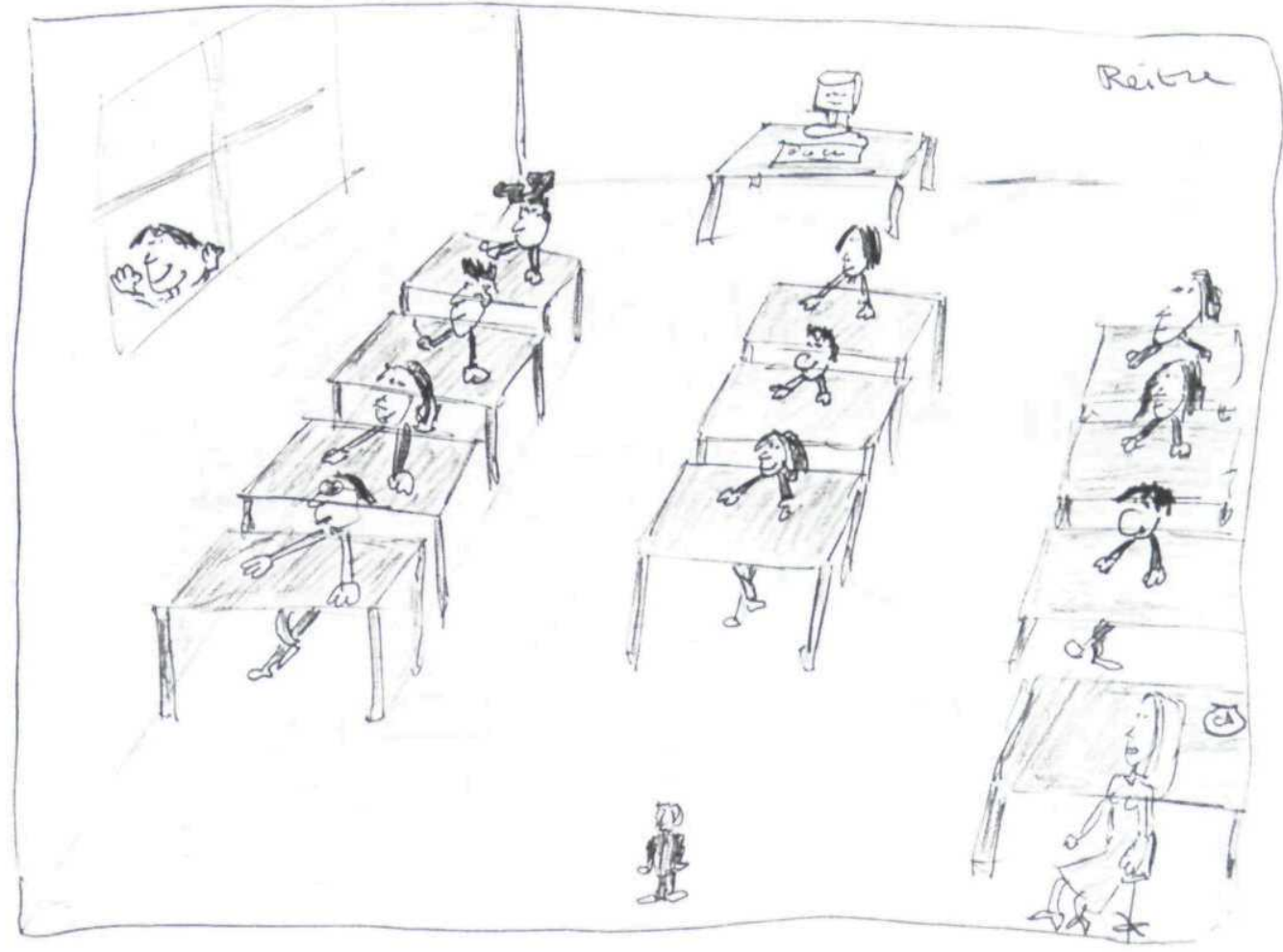

Figure 3. Drawing by Reitze

7. Concerns about themselves as teachers. These are drawings of students picturing themselves as very small or insignificant or very big (both out of proportion) (see Figure 3).

8. Concerns about the choice of becoming a teacher. These are drawings of students pictured as having doubts about their choice of becoming a teacher or their ability to become a good teacher.

Some of these concern categories are quite similar to the concerns formulated by Fuller and Bown (1975), like the concerns about (all) pupils, concerns about discipline in the classroom, concerns about the opinion of the mentor, concerns for the learning of the pupils and concerns for matters outside the classroom. Other of the concern categories that emerged from the drawings are different, like concerns about a cosy atmosphere in the classroom, concerns about themselves as teachers and concerns about the choice of becoming a teacher. The major characteristic, however, of the concern categories based on the drawings is that not only the verbal concern but also the content of the concern, in all its detail, is visible in the drawings.

The results of the scoring procedure by the three raters are presented in Table 3, which shows whether or not a concern is present in the drawing and the intensity of the concern. From Table 3 one can read that some concerns are more prominent in 


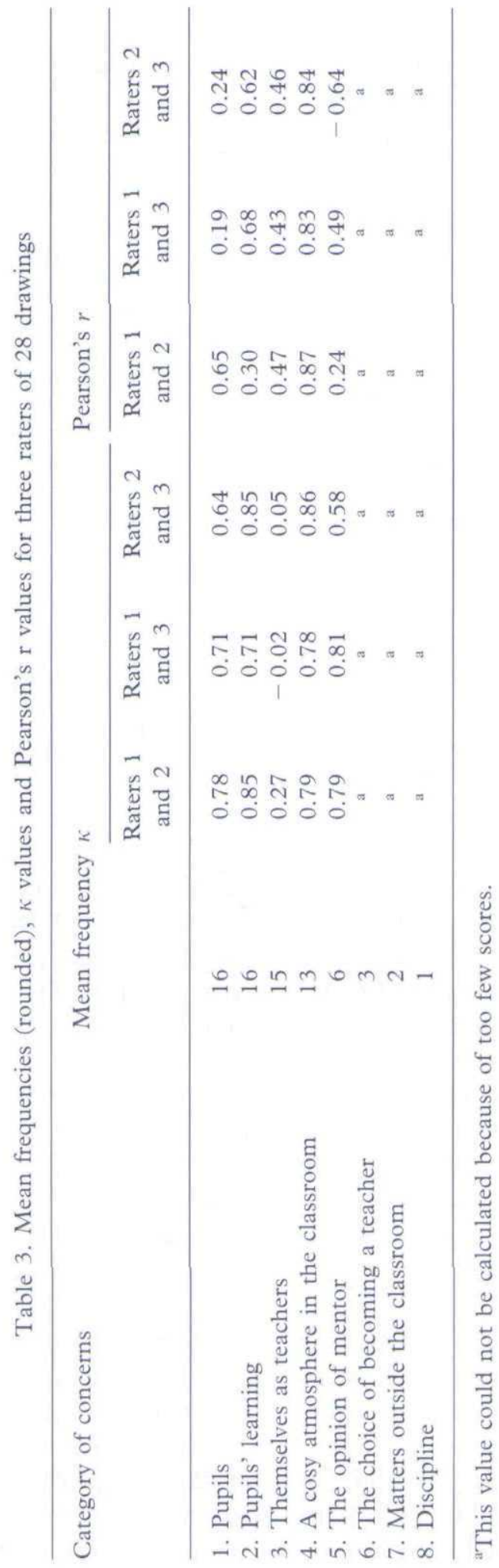


Table 4. Percentages of presence of concern categories in the selected 28 drawings and mean scores of two raters at times 1 and 2

\begin{tabular}{|c|c|c|c|c|c|c|c|c|}
\hline \multirow[t]{3}{*}{ Category of concerns } & \multicolumn{4}{|c|}{ Measure 1} & \multicolumn{4}{|c|}{ Measure 2} \\
\hline & \multicolumn{2}{|c|}{ Rater 1} & \multicolumn{2}{|c|}{ Rater 2} & \multicolumn{2}{|c|}{ Rater 1} & \multicolumn{2}{|c|}{ Rater 2} \\
\hline & $\%$ & Mean & $\%$ & Mean & $\%$ & Mean & $\%$ & Mean \\
\hline 1. Pupils learning & 71 & 1.5 & 79 & 1.6 & 36 & 1.4 & 43 & 1.5 \\
\hline 2. Pupils & 57 & 2.0 & 57 & 1.9 & 57 & 1.4 & 50 & 1.3 \\
\hline 3. A cosy atmosphere & 50 & 1.9 & 64 & 1.9 & 36 & 1.2 & 43 & 1.5 \\
\hline 4. Opinion of mentor & 43 & 1.8 & 29 & 2.8 & 7 & 1.0 & 7 & 1.0 \\
\hline 5. Themselves as teachers & 29 & 2.3 & 50 & 2.3 & 50 & 1.9 & 43 & 1.8 \\
\hline 6. Discipline & 14 & a & 7 & a & 0 & a & 0 & a \\
\hline 7. The choice to become a teacher & 7 & a & 7 & a & 14 & a & 14 & a \\
\hline 8. Matters outside the classroom & 0 & a & 0 & a & 14 & a & 14 & a \\
\hline
\end{tabular}

aThis value could not be calculated because of too few scores.

the 28 drawings selected (from 64) than others: concerns about pupils, concerns about pupils learning, concerns about a cosy atmosphere in the class and concerns about themselves as teachers. Some concerns seem almost absent, such as concerns about the choice of becoming a teacher, concerns about matters outside the classroom and concerns about discipline. For these concerns the measure of agreement could not be assessed because of too few scores.

It is evident from Table 3 that the inter-rater reliability is not very high. Nevertheless, according to criteria found in the literature, most of the values for $\kappa$ are satisfactory, except for concerns about themselves as teachers (Landis \& Koch, 1977). We did not use this last category in the conclusions. The values for the Pearson's correlations may, on average, be called reasonable. The measure of agreement is on average highest for the first pair of raters. The frequency and mean scores of these two raters have, therefore, been taken as the basis for further analysis.

Table 4 shows the changes that can be seen between the first and second drawings of the student teachers. One can read from Table 4 that concerns about pupils, the learning of pupils, a cosy atmosphere and the opinion of the mentor are prominent in the first drawings of student teachers, just before their first practice teaching period. The second batch of drawings still shows concerns about pupils, the learning of pupils and a cosy atmosphere, but hardly any concerns about the opinion of the mentor. It is noteworthy that the overall frequency of the concerns in the drawings diminishes.

In general, the results of the drawings, like those of the card sorting instrument, show little change in overall concerns, except for the concern about the opinion of the mentor. But, again, there are indications of a move from a more idealized view of teaching towards a more realistic view. This becomes visible in the drawings through a decrease in the use of colour, plants, flowers, pictures and furniture in the classrooms, as well as a through a decrease in activities such as singing and dancing and through less idealized visualizations of pupils. Girls with nice long hair who are 


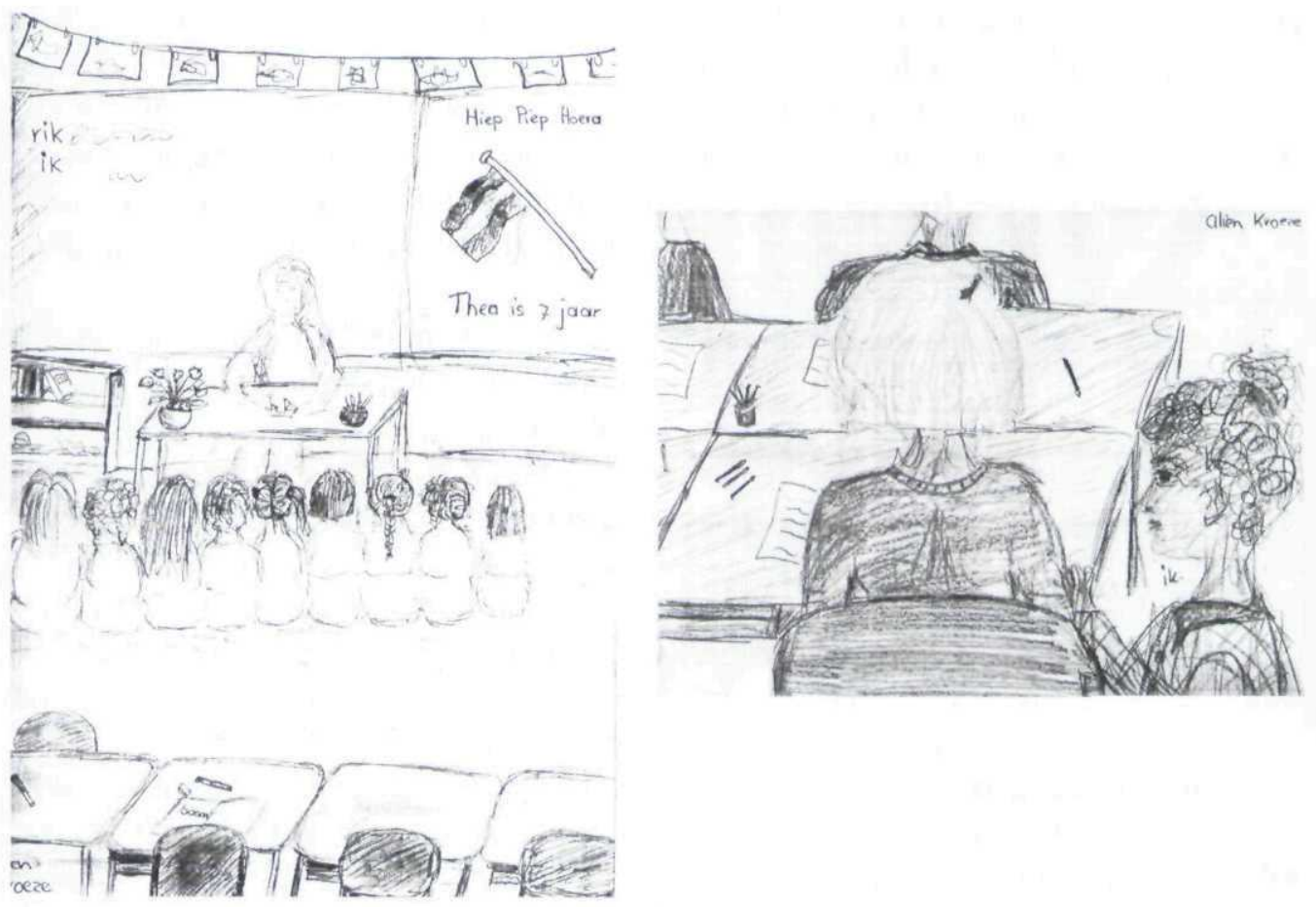

Figure 4. Drawings by Eileen

looking at the teacher and listening frequently appear in the first drawings, but are less visible in drawings made towards the end of the first year. Eileen's first and second drawings (Figure 4) illustrate the general move away from a more romantic to a more realistic view of teaching, which is in line with the findings by Fuller and Bown (1975) and Cole and Knowles (1993). Her first drawing is an example of a drawing in which concerns for pupils and for a cosy atmosphere are visible. In her second drawing we can still see concerns about the pupils, but there is less emphasis on a pleasant atmosphere. During the interview Eileen said about her first drawing that she drew an imaginary class: 'This is a nice class. The children listen well. You can teach them things'. She speaks about her second drawing not without enthusiasm, but with more knowledge of what goes on in the classroom:

Here I am explaining something to a child. That is something I often did during my work at school. I was in a mixed age class and when the teacher was busy with one group, I helped the other group by explaining something to them. It had to be done quietly, so I squatted on my heels.

\section{Conclusions and discussion}

A comparison of the results of the card sorting instrument and the drawings shows agreement on the nature of the concerns of student teachers. Students express 
concerns both about pupils and about the learning of pupils, especially their motivation, and the pedagogical context of education. Students show average concerns about things that, in their opinion, are not essential to the task of teaching, such as assessment or maintaining discipline. Students seem to have few or no concerns about things that have little bearing on the pupils or the instructional task of teachers such as things that happen outside the classroom. On the whole, student teachers seem to become more realistic.

Although there is general agreement about the outcomes of the analysis of the card sorting instrument and the drawings, there are some concerns that emerge more clearly from the drawings than the cards. This is particularly true of 'a cosy atmosphere in the classroom'. The students in the interviews also emphasized this issue. The students considered a good atmosphere a precondition for their own functioning and for pupil learning.

The results show that the concerns of student teachers did not develop much during the first year. All the results indicate that student teachers seem to become more realistic. From the interviews we learned that this is mainly caused by the experiences of the students during their teaching practice.

As far as research question 5 , 'can concerns be assessed in a valid and reliable way by using drawings?' is concerned, we consider the agreement in the results found with the card sorting instrument and the drawings, as well as the reasonable inter-rater reliabilities, to be indications of the quality of both instruments. It seems, however, that there is a difference between the two instruments. A possible explanation of the divergence in results may be found in the nature of the instruments. The cards are based upon a standard list and the students could only make use of the given items. The card sorting instrument also functions as a more cognitive instrument. When they made the drawings the students were free to draw what they wanted and it may be argued that students use more subjective knowledge when they make a drawing. The five categories of concerns we found evidence for in the drawings have a more general character.

The period that students spent in school that particular year was very short. As a consequence they may not have been fully engaged in classroom activities. The lack of change in the concerns may be caused by this limited teaching experience of students. It would be interesting to investigate the influence of longer periods of school practices upon the concerns of students.

The similarities between the outcomes of the analyses of the card sorting instrument and the drawings may be caused by the initial framework used by the researcher. On the other hand, it is no surprise that student teachers express concerns about pupils, the learning of the pupils and about themselves in their drawings. The differences between the outcomes indicate that the drawings give additional information about the concerns of student teachers.

Although drawings elicit responses that differ from those of more traditional, verbal research techniques, the use of drawings as a research method is not without problems. One of the problems is the ability of people to make drawings that reflect what they want to express. Weber and Mitchell (1995, p. 35) acknowledge that 
... few adults in Western society develop a visual vocabulary and drawing skills much beyond elementary school level, probably because drawing is not as highly valued as reading and writing.

One of the students interviewed drew a picture that was rather sober and said she did so because of her limited artistic skill. Nevertheless, most of the pictures are strong and imaginative and reflect the feelings of the students in various ways, from drawings in black and white to express stress and anxiety to bright colours to express love for children.

Our results show that we found a fruitful entrance by taking drawings as a basis for measuring concerns. The validity of the drawings seems to us somewhat greater than the prefabricated card items derived from a long list of concerns. They connect the individual to the general aspects of concerns. More than the card sorting instrument, the drawings appear to reveal underlying images and concerns coloured by needs and feelings, such as the need for cosiness and feelings of competence, aspects confirmed by the interviews. In this respect, traditional research instruments seem to create a certain one-sidedness in the kind of perceptions measured (Wubbels, 1992; Korthagen, 1993), as they focus more on purely rational elements. One of the characteristics of the drawings that surprised us was the fact that students were able to remember in remarkable detail their feelings and thoughts represented in drawings they made several months before.

The general character of concerns of student teachers shown in their drawings makes drawings a useful instrument for measuring development and for reflection by student teachers and teacher educators, both individually and in a group. This relationship between research and practical use is to us of great importance. In this way theory and practice can influence each other and this may lead to theory-based practice in teacher education.

Our results confirm that images may play an important role in gathering knowledge about teacher development (compare Calderhead \& Robson, 1991). Drawings help to clarify factors that in other research receive less attention, especially the less conscious and less rational aspects of teacher development (Weber \& Mitchell, 1975). In this respect our study may contribute to the development of research approaches making such aspects explicit. On the other hand, for valid conclusions about individual student's concerns, interviews about the results found with the card sorting technique or the drawings remain necessary. For example, a high score on an item such as 'too many pupils in one class' can indicate concerns about self or survival as well as instructional concerns or pupils' needs concerns.

Research using drawings fits into the new methodology of 'image-based research' as proposed by Prosser (1998). We believe we have succeeded in finding a fruitful balance between this new research approach and a more traditional one, but more research is needed. Moreover, it seems important to experiment with variations in the instructions for making the drawings, both with respect to what should be drawn and with respect to ways of facilitating the process of imagining (see also Huibregtse et al., 1994).

In our study we limited ourselves to analyses on the group level. Another line of research would be to use the card sorting instrument and the drawings as the basis 
for a more person-centred research approach, from a biographical perspective (cf. Kelchtermans, 1993). This could give us more insight into how changes or the absence of change are influenced by what Kelchtermans calls 'critical persons' and 'critical incidents'.

Finally, we think we have succeeded in developing instruments which can also be used by teacher educators with the aim of developing more understanding of their student teachers' concerns. As such, these instruments may contribute to the development of what Korthagen and Kessels (1999) call 'realistic teacher education', i.e. teacher education that builds on student teachers' actual concerns.

\section{Notes on contributors}

Anja Swennen is a teacher educator and consultant on teacher education the Vrije Universiteit Amsterdam. Her main areas of interest are the professional development of teachers and teacher educators.

Ton Jörg, psychologist and education researcher at the IVLOS Institute of Education of Utrecht University in The Netherlands, is interested in the learning of students as a process in time and the modelling of that process and the effects of it.

Fred Korthagen is professor of education at the University of Utrecht in The Netherlands and the Vrije Universiteit Amsterdam. He coordinates research on teaching and teacher education and gives professional development courses to teachers, school principals and teacher educators.

\section{References}

Borich, G. D. (1996) Effective teaching methods (Merrill, NJ, Prentice Hall).

Burden, P. (1990) Teacher development, in: W. R. Houston (Ed.) Handbook of research on teacher education (New York, Macmillan), 311-328.

Calderhead, J. (1989) Reflective teaching and teacher education, Teaching and Teacher Education, $5(1), 42-51$.

Calderhead, J. \& Robson, M. (1991) Images of teaching: student teacher's early conceptions of classroom practice, Teaching and Teacher Education, 7(1), 1-8.

Cole, A. \& Knowles, J. G. (1993) Shattered images: understanding expectations and realities of field experiences, Teaching and Teacher Education, 9(5/6), 457-471.

Connelly, F. M. \& Clandinin, D. J. (1984) Personal practical knowledge at Bay Street School: ritual, personal philosophy and image, in: R. Halkes \& J. H. Olson (Eds) Teacher thinking, a new perspective on persisting problems in education (Lisse, Swets \& Zeitlinger), 134-148.

Denis, M. (1991) Image E cognition (Harvester Wheatsheaf).

Fuller, F. F. (1969) Concerns of teachers: a developmental conceptualization, American Educational Research fournal, 6(2), 207-226.

Fuller, F. F. \& Borich, G. (1988) Teachers concerns checklist, in: G. Borich (Ed.) Effective teaching methods (Toronto, Merrill), 62-72 and 321-322.

Fuller, F. F. \& Bown, D. (1975) Becoming a teacher, in: K. Ryan (Ed.) Teacher education, 74th Yearbook of the National Society for the Study of Education, Part II (Chicago, University of Chicago Press), 25-52. 
Guillaume, A. \& Rudney, G. (1993) Student teachers' growth toward independence: an analysis of their changing concerns, Teaching and Teacher Education, 9(1), 65-80.

Huibregtse, I., Korthagen, F. \& Wubbels, T. (1994) Physics teachers' conceptions of learning, teaching and professional development, International fournal of Science Education, 16(5), 539-561.

Janssens, S. (1989) Een onderzoek naar bekommernissen van aspirant-leraren [Research on concerns of preservice teachers], in: S. Janssens, J. J. Peters \& G. Tistaert (Eds) Leraar als beroep [Teaching as a profession] (Amsterdam, Swets \& Zeitlinger), 23-33.

Kelchtermans, G. (1993) Getting the story, understanding the lives: from career stories to teachers' professional development, Teaching and Teacher Education, 9(5/6), 443-456.

Korthagen, F. (1993) Two modes of reflection, Teaching and Teacher Education, 9(3), 317-326.

Korthagen, F. A. J. \& Kessels, J. P. A. M. (1999) Linking theory and practice: changing the pedagogy of teacher education, Educational Researcher, 28(4), 4-17.

Landis, J. R. \& Koch, G. G. (1977) The measurement of observer agreement for categorical data, Biometrics, 33, 159-174.

Packer, M. \& Scott, B. (1992) The hermeneutic investigation of peer relations, in: L. Winegar \& J. Valsiner (Eds) Research and methodology, Vol. 2. Children's development within social context (Hillsdale, NJ, Lawrence Erlbaum Associates), 75-111.

Pigge, F. \& Marso, R. (1987) Relationships between student characteristics and changes in attitudes, concerns, anxieties and confidence about teaching during teacher preparation, fournal of Educational Research, 81(2), 109-115.

Proces Management Lerarenopleidingen (1998) Gemeenschappelijk curriculum PABO [National curriculum teacher education for primary teaching] (Ten Brink, Meppel).

Prosser, J. (1998) Image-based research, a source-book for qualitative researchers (London, Falmer Press).

Smith, D. J. \& Sanche, R. P. (1992) Saskatchewan Interns' concerns at three stages of a four-month practicum, The Alberta fournal of Educational Research, 38(2), 121-132.

Smith, D. J. \& Sanche, R. P. (1993) Interns' personally expressed concerns: a need to extend the Fuller model? Action in Teacher Education, 15(1), pp. 36-41.

Veenman, S. (1984) Perceived problems of beginning teachers, Review of Educational Research, 54, $143-178$.

Weber, S. J. \& Mitchell, C. (1995) That's funny you don't look like a teacher! (London, Falmer Press).

Weber, S. J. \& Mitchell, C. (1996) Drawing ourselves into teaching: studying the images that shape and distort teacher education, Teaching and Teacher Education, 12(3), 303-313.

Wubbels, T. (1992) Taking account of student teachers' preconceptions, Teaching and Teacher Education, 8(2), 137-149. 
Copyright of European Journal of Teacher Education is the property of Carfax Publishing Company and its content may not be copied or emailed to multiple sites or posted to a listserv without the copyright holder's express written permission. However, users may print, download, or email articles for individual use. 